\title{
Top-down control of lobster in the Gulf of Maine: insights from local ecological knowledge and research surveys
}

\author{
Stephanie A. Boudreau*, Boris Worm \\ Biology Department, Dalhousie University, Halifax, Nova Scotia B3H 4J1, Canada
}

\begin{abstract}
American lobster Homarus americanus landings in the Gulf of Maine have been steadily increasing since the 1980s. As a result, lobsters now support one of the most important fisheries in the USA and Canada. One hypothesis for this pattern is that lobsters have been released from predation as groundfish stocks declined, expanding both in abundance and habitat. Lobster habitat is typically rocky substrate of the inshore region, which is difficult to sample. Some long-term fisheries-independent abundance indices for lobsters and their predators are available for the Gulf of Maine in the USA, but not in Canada. To try and fill those research gaps, we designed a local ecological knowledge (LEK) survey. Semi-structured interviews of 42 fishermen in southwest Nova Scotia, Canada, revealed consistent trends of the depletion of large groundfish, particularly Atlantic cod Gadus morhua. Eighty-three percent of fishermen concluded this depletion was the main reason for an observed increase in lobster abundance. They also reported the expansion of lobsters to new habitats and depths. We further show that the proposed top-down control mechanism is independently supported by USA research trawl surveys, which revealed a negative correlation $(p<0.05)$ between the summed abundance indices of 5 groundfish predators of lobster and lobster abundance $\left(\mathrm{kg} \mathrm{tow}^{-1}\right)$ at time lags ranging from 0 to $9 \mathrm{yr}$. Survey-based diet data also corroborated direct observations by fishermen on lobster predation by groundfish. These results suggest that LEK may be a useful supplementary tool to investigate the ecosystem effects of fishing, particularly in data-poor situations.
\end{abstract}

KEY WORDS: Local ecological knowledge $\cdot$ American lobster · Gulf of Maine $\cdot$ Ecosystem effects of fishing $\cdot$ Atlantic cod

\section{INTRODUCTION}

Commercially harvested invertebrate populations often exhibit abrupt declines under intense fishing pressure and can be slow to recover. Alaskan red king crab Paralithodes camtschaticus (Orensanz et al. 1998), abalones Haliotis spp. (Tegner \& Dayton 2000), green sea urchins Strongylocentrotus droebachiensis (Berkes et al. 2006) and oysters (e.g. Crassostrea virginica, Kirby 2004) are well-documented examples of this phenomenon. American lobster Homarus americanus in the Gulf of Maine (GOM) of the NW Atlantic Ocean, however, shows a different trend characterized by long-term sustainability and recent increases in reported landings (ASMFC 2006, Steneck 2006).
In the present study we focus on lobster fishing area (LFA) 34 in SW Nova Scotia, which is part of the Canadian GOM. It is one of the most productive lobster fishing areas in the world, accounting for approximately $40 \%$ of Canadian lobster landings every year. The annual lobster fishing season in LFA 34 lasts from late November to the end of May, with an estimated 70 to $90 \%$ of fishable biomass removed every year with baited traps. The fishery is managed by limiting licences, gear and vessel regulations, minimum carapace size and protection of egg-bearing females (DFO 2006a).

Despite intense fishing pressure, the lobster population in the GOM has been increasing since the 1980s, and in the 2004/2005 fishing season, LFA 34 landings were approximately 5 times higher than in 1980/1981 
(Fig. 1A). Likewise, increases have been documented in landings, abundance indices and recruitment of lobster in the United States' part of the GOM (Fig. 1B,C). Observed increases in landings, abundance and recruitment are unique to this region, as an observed decline of lobster landings has been observed in areas south of the GOM, as well as in the Northumberland Straight (LFA 25) and parts of Newfoundland (ASMFC 2006, DFO 2006b, 2007), Canada. The reason for this increase is not well understood; one hypothesis is that the increase in lobster landings is partially explained by the rapid decline in predatory groundfish stocks, such as Atlantic cod Gadus morhua, in the NW Atlantic, leading to a predatory release (Frank et al. 2005, Steneck 2006, Zhang \& Chen 2007, Collie et al. 2008). For example, while cod spawning stock biomass in the Canadian GOM decreased from $65000 \mathrm{t}$ in 1980 to
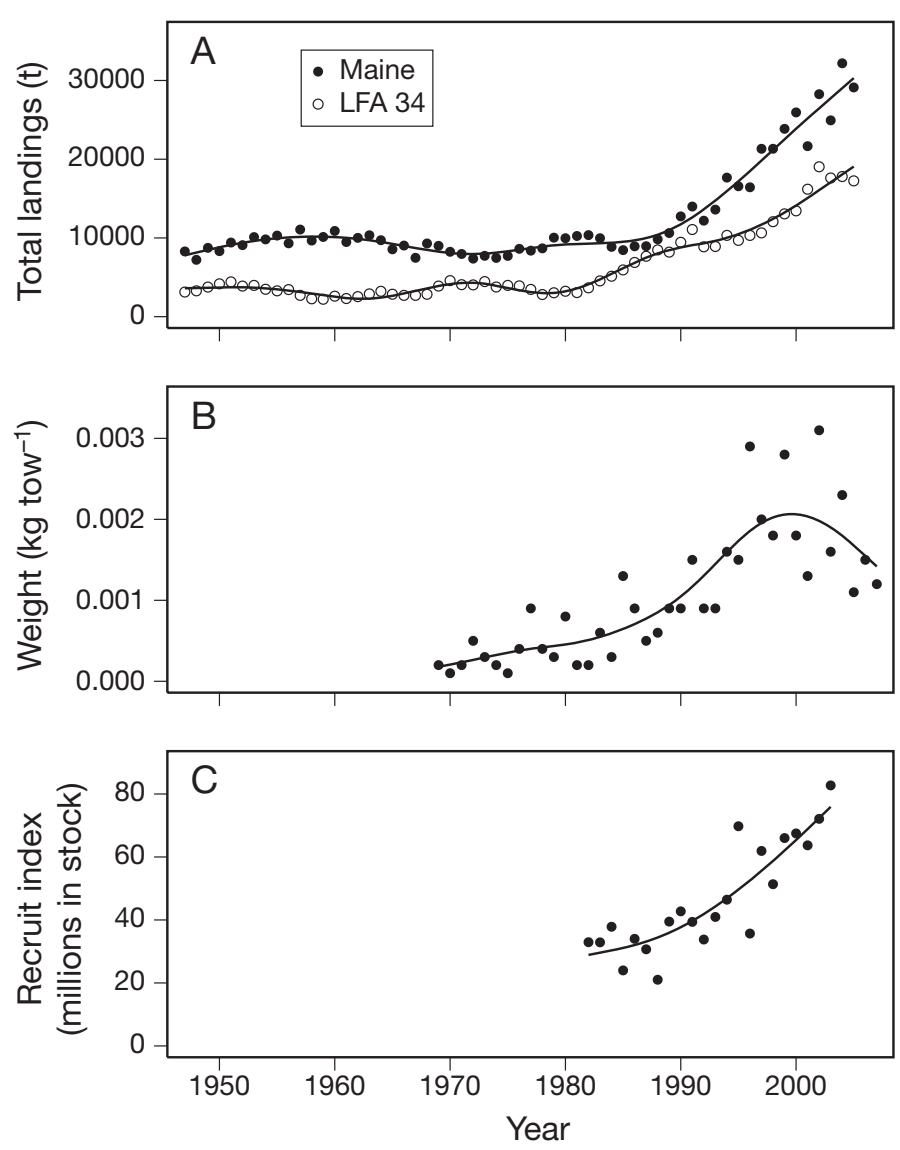

Fig. 1. Homarus americanus. American lobster trends in the Gulf of Maine: (A) from 1947 to 2005, lobster landings (t) in Maine from Maine's Department of Marine Resources (solid circles) and lobster fishing area (LFA) 34 from the Canadian Department of Fisheries and Oceans (open circles), (B) from 1969 to 2007, lobster abundance indices $\left(\mathrm{kg} \mathrm{tow}^{-1}\right)$ from the National Marine Fisheries Service research surveys, and (C) from 1983 to 2003, lobster recruit abundance index (millions in stock) from the Atlantic States Marine Fisheries Commission. Trend lines on all panels were derived from a general additive model
$9000 \mathrm{t}$ in 2008 (Clark \& Emberley 2009), the lobster population increased.

The NW Atlantic is assumed to have been a top-down dominated ecosystem before being subjected to exploitation (Worm \& Myers 2003, Steneck et al. 2004, Frank et al. 2007). Fishing has altered this by removing most of the larger predators, which in turn has led to significant ecological change (Lotze \& Milewski 2004, Steneck et al. 2004). For example, the GOM is thought to have gone through 3 phase shifts in nearshore habitats, from a dominance of predatory groundfish (e.g. Atlantic cod, haddock Melanogrammus aeglefinus, Atlantic halibut Hippoglossus hippoglossus and wolffish Anarhichas lupus) to herbivorous invertebrates (sea urchins) and then to predatory invertebrates (Cancer spp., lobster) (Steneck et al. 2004). Another study documented a trophic cascade from large groundfish to pelagic forage fish, plankton, marine mammals and benthic invertebrates on the Scotian Shelf (Frank et al. 2005); it was thought to be a consequence of overfishing, possibly mediated by changes in temperature and stratification. An example of an invertebrate population being released from predation is provided by a metaanalysis of cod and shrimp Pandalus borealis biomass in the North Atlantic Ocean (Worm \& Myers 2003). Cod and shrimp biomass, as estimated by research trawl surveys, were found to be inversely correlated, leading to large increases in shrimp abundance as cod stocks declined. Collectively, these results lead to interesting questions about ecosystem-based management and the number of predators that can be removed from a system before forcing it into another ecological state (Frank et al. 2007).

A second hypothesis for the observed increase in lobster landings is the advancement of effective fishing effort. The nominal fishing effort in LFA 34 has remained relatively constant over the last few decades; there has been an established fishing season since the 1900s, trap limits have remained between 375 and 400 per fisherman and no new licences have been issued since 1968 (Pezzack et al. 2001). However, there have been changes in the effective fishing effort, in terms of improvements in fishing technology, vessels and expansion of the area fished (FRCC 1995, 2007, DFO 2006a). Prior to the mid-1970s, lobster fishing in LFA 34 occurred in nearshore waters of $<55 \mathrm{~m}$ depth, and then began to expand to midshore waters, a trend which continued through the 1990s (Pezzack et al. 2001). These changes are not unique to LFA 34; in the Magdalen Islands in the northern Gulf of St. Lawrence, Canada, fishing capacity expansion coincided with an in- 
crease in lobster landings (Gendron \& Archambault 1997, Gendron et al. 2000). In addition, interviews of fishermen documented an increase in vessel size and width to facilitate the transport of more traps (Gendron \& Archambault 1997). Advanced technologies for navigation and depth sounding have been quickly adopted and have spurred the discovery of new lobster grounds. The results from the study suggested that the increase in catch per unit effort in the Magdalen Islands resulted both from an increase in lobster biomass and improved fishing technology (Gendron et al. 2000).

Here we were interested in learning how interactions among predatory groundfish and lobsters may have played out in the inshore region of SW Nova Scotia. Recent recruitment of lobsters in this region has been strong (ASMFC 2006), implying that environmental conditions have been favourable for early lobster life stages. However, currently there are no long-term fisheries-independent estimates of lobster abundance in LFA 34, and lobsters have only recently been recorded in the Canadian Department of Fisheries and Oceans (DFO) research trawl surveys. The research surveys typically cover offshore regions, but most lobster habitat is located inshore at depths of $<55 \mathrm{~m}$. In order to fill some of the knowledge gaps for this inshore ecosystem, we designed a local ecological knowledge (LEK) survey for the fishermen of LFA 34. The goals of the survey were to record the LEK of fishermen of the coastal LFA 34 ecosystem, with respect to lobsters and groundfish, and compare available fisheries-independent data from the United States to the survey results. We were further interested in the possible effects of climate, disease, changes in prey abundance and fishing effort on lobster abundance and catches, as recorded by these local experts.

\section{MATERIALS AND METHODS}

LEK is 'the knowledge held by a group about their local ecosystem' (Olsson \& Folke 2001) and considers humans as part of the ecological system (Murray et al. 2006). Trends from LEK interviews can be quantified on an ordinal scale and may be used to complement scientific information for resource management (Neis et al. 1999b).

LFA 34 was selected for the interviews as it is commercially important to Atlantic Canada and has shown a striking increase in landings since the 1980s (Fig. 1A; DFO 2006a). Forty-two lobster fishermen, 4 of whom were retired, out of approximately 937 lobster fishing licence holders in LFA 34 (DFO 2006a) were interviewed from June to October 2007 during the LFA's seasonal closure.
Survey design and questions. A consent form and semi-structured interview were designed and approved by Dalhousie University's Social Sciences Research Ethics Board. Questions were formulated from ecological hypotheses linked to the fluctuations in the American lobster Homarus americanus population in the NW Atlantic. Specifically, the survey addressed the observed increase of lobster abundance and landings in LFA 34. It was structured around 6 different variables: predation, conservation, climate, prey abundance, disease and fishing effort. Several recent studies (Neis et al. 1999a,b, Hutchings \& Ferguson 2000, Davis \& Wagner 2003, Sáenz-Arroyo et al. 2005a,b) were used as references for the design. Further advice on design and execution was sought from a number of experts in ecological knowledge surveys. The fishermen were contacted first by telephone, and arrangements were made to be interviewed in person. The interview began with the fisherman signing the consent form, then an explanation of the research, leading into the interview questions. The survey ended with a free-form discussion in which the interviewee could mention any topics not previously covered. There were 2 versions of the respondent's consent form, the first mentioned our interest in the loss of groundfish as a potential mechanism for the increased lobster landings and the second did not.

The 3 main questions of interest about the inshore ecosystem were:

(1) Why do you think there are so many more lobsters in the last 20 yr in LFA 34 than there were in the 1950s?

(2) In your experience, what fish have you cut open and found lobster in its stomach?

(3) Have you observed any other changes in fish or invertebrate species abundance since 1980 in the inshore region?

Participants. The goal was to target a certain demographic of the licence holders, predominantly middleaged fishermen with a relatively long history of fishing in the inshore region of LFA 34. To create an initial list of potential participants we consulted the LFA 34 fishermen's representative, community members and the DFO, who identified local experts for the inshore ecosystem. However, the majority of participants were identified by their peers through recommendations at the end of the interviews (Davis \& Wagner 2003). Such snowball sampling schemes (also called chain referral or reputational sampling; Neuman 2000) are useful in situations where the information desired is perceived as 'sensitive' and finding individuals willing to participate in the survey is a challenge (Lopes et al. 1996). This non-random sampling methodology is used in the social sciences (Neuman 2000) and has been used successfully in similar marine LEK studies (e.g. Neis et al. 1999a,b, Hutchings \& Ferguson 2000). 
Data analysis. The various responses to each question were tallied and percentages with $95 \%$ confidence intervals (CIs) were calculated. The prop.test command in R was used to create proportions, and CIs were calculated using a modified Wilson's method, correcting for the assumption of normality, with the Yates correction for continuity, which is appropriate for discrete data (Newcombe 1998, R Development Core Team 2008). This method also allows for asymmetrical CIs bounded between 0 and 1 .

To test for possible age-related biases among the respondents' answers, a series of logistic regression analyses were performed with 'years of fishing experience' as the explanatory variable. Answers that were not originally recorded binomially were grouped and converted. For example, if the fisherman reported first starting to fish midshore waters in the 1980 s or before (i.e. before the observed increase in landings), the answer was assigned 0, if it was in the 1990s or after, it was assigned 1.

Data from research trawl surveys were compared with average responses from our LEK survey, if available. For predator diet data, we compiled occurrences of lobster from the stomach content databases of the Northeast Fishery Science Center (NEFSC) in Woods Hole, Massachusetts (Table 1) and the Maine and New Hampshire inshore research trawl survey (Maine Department of Marine Resources, DMR); these data were tallied and converted to proportions, with 95\% CIs calculated as above. We selected 5 groundfish species with available abundance indices that were identified as predators of lobster from both the LEK survey results and stomach contents database: Atlantic cod, longhorn sculpin Myoxocephalus octodecemspinosus, wolffish, cusk Brosme brosme and monkfish Lophius americanus. The groundfish and lobster abundance indices $\left(\mathrm{kg} \mathrm{tow}^{-1}\right)$ in the GOM from the National Marine Fisheries Service (NMFS) research trawl survey were log-transformed for normality and correlated using linear regression (see Fig. 3). Conventionally, these data are analyzed with time lags to reflect the average time of recruitment of GOM lobster to the fishery and the predation of groundfish on various lifestages of lobster. It takes lobsters in LFA 34 from 7 to 8 yr to grow to minimum legal size (DFO 1997). To address this, correlograms were constructed with lags from 0 to $10 \mathrm{yr}$. Lobster landings for Maine were accessed from the DMR website (www.maine.gov/dmr/ $\mathrm{rm} /$ lobster/lobdata.htm).

\section{RESULTS}

Interviewed fishermen were thoughtful in their replies, had an average of $35 \mathrm{yr}$ of fishing experience (range: 16 to $51 \mathrm{yr}$ ), were on average $55 \mathrm{yr}$ old (range: 34 to $84 \mathrm{yr}$ old) and $91 \%$ of their income came from the lobster fishing industry (range: 30 to $100 \%$ ). The average fisherman interviewed possessed 5 different fishing licences or permits (range: 2 to 8 ). The majority of the fishermen interviewed were from Yarmouth County (26), followed by Digby County (9) and Shelburne County (7). Fishermen from a total of 20 harbours were surveyed, with between 1 and 9 of the fishermen interviewed fishing from a particular harbour. Contact with fishermen was initiated in Yarmouth County, and, as a result, it was more difficult to snowball-sample fishermen in the other 2 counties. The

Table 1. Homarus americanus. Species found with lobster in their stomachs from the stomach contents database (1973 to 2005) of the Northeast Fishery Science Center, ordered by percentage with 95\% confidence intervals (CI)

\begin{tabular}{|c|c|c|c|c|c|}
\hline Predator & Species name & Lobsters & Stomachs & Percent & $95 \%$ CI \\
\hline Smooth dogfish & Mustelus canis & 25 & 7145 & 0.35 & $0.23-0.52$ \\
\hline Atlantic cod & Gadus morhua & 58 & 18818 & 0.31 & $0.23-0.40$ \\
\hline Atlantic halibut & Hippoglossus hippoglossus & 1 & 365 & 0.27 & $0.01-1.52$ \\
\hline Thorny skate & Raja radiata & 5 & 3279 & 0.15 & $0.05-0.36$ \\
\hline Smooth skate & Raja senta & 1 & 869 & 0.12 & $0.00-0.64$ \\
\hline Longhorn sculpin & Myoxocephalus octodecemspinosus & 9 & 11116 & 0.08 & $0.04-0.15$ \\
\hline Haddock & Melanogrammus aeglefinus & 6 & 8132 & 0.07 & $0.03-0.16$ \\
\hline Spiny dogfish & Squalus acanthias & 43 & 63837 & 0.07 & $0.05-0.09$ \\
\hline Little skate & Raja erinacea & 16 & 25818 & 0.06 & $0.04-0.10$ \\
\hline Sea raven & Hemitripterus americanus & 4 & 6693 & 0.06 & $0.02-0.15$ \\
\hline Red hake & Urophycis chuss & 8 & 16802 & 0.05 & $0.02-0.09$ \\
\hline White hake & Urophycis tenuis & 5 & 13883 & 0.04 & $0.01-0.08$ \\
\hline Monkfish & Lophius americanus & 3 & 9573 & 0.03 & $0.01-0.09$ \\
\hline Winter skate & Raja ocellata & 4 & 16358 & 0.02 & $0.01-0.06$ \\
\hline Winter flounder & Pseudopleuronectes americanus & 1 & 7966 & 0.01 & $0.00-0.07$ \\
\hline Spotted hake & Urophycis regia & 1 & 12084 & 0.01 & $0.00-0.05$ \\
\hline Silver hake & Merluccius bilinearis & 1 & 45646 & 0.00 & $0.00-0.01$ \\
\hline
\end{tabular}


location of the interviewee's home harbour did not necessarily reflect where they lived.

When asked why lobster landings had increased over the last $20 \mathrm{yr}, 83 \%$ of respondents said that the loss of predators was the major reason, $33 \%$ also attributed increased landings to recent increases in fishing effort and the expansion to deeper waters and $21 \%$ thought that conservation measures, such as gear restrictions and the protection of egg-bearing females, were helping to increase the population (Fig. 2A). Finally, 19\% identified a different factor that may have influenced the increase, such as changes in climate or water temperatures. Seventy-four percent were concerned that the population may eventually decline due to increasing fishing effort, the targeting of large lobster and the depletion of brood stock. Fifty-two percent mentioned that they would be supportive of a maximum legal size limit to preserve the large individuals.

Of the 17 fishermen that received the first version mentioning our interest in the decline of groundfish abundance as a mechanism for the increase in lobster landings, $82 \%$ mentioned that the 'loss of predators' was, in their view, a mechanism for increased lobster landings. Of the 25 individuals that received the second version, $84 \%$ gave the same reply. Fisher's exact test for count data revealed no significant difference $(p=1)$.

\section{Predator diet}

To examine the potential mechanism of the hypothesized predator release effect, fishermen were asked which fish they had dressed in their careers and found a lobster in its stomach contents (Fig. 2B). Largebodied predators, such as cod (95\% reported finding a lobster in stomach contents), wolffish (74\%) and cusk $(38 \%)$, were listed, in addition to sculpin (most likely longhorn sculpin, $81 \%$ ). To complement the fisher-
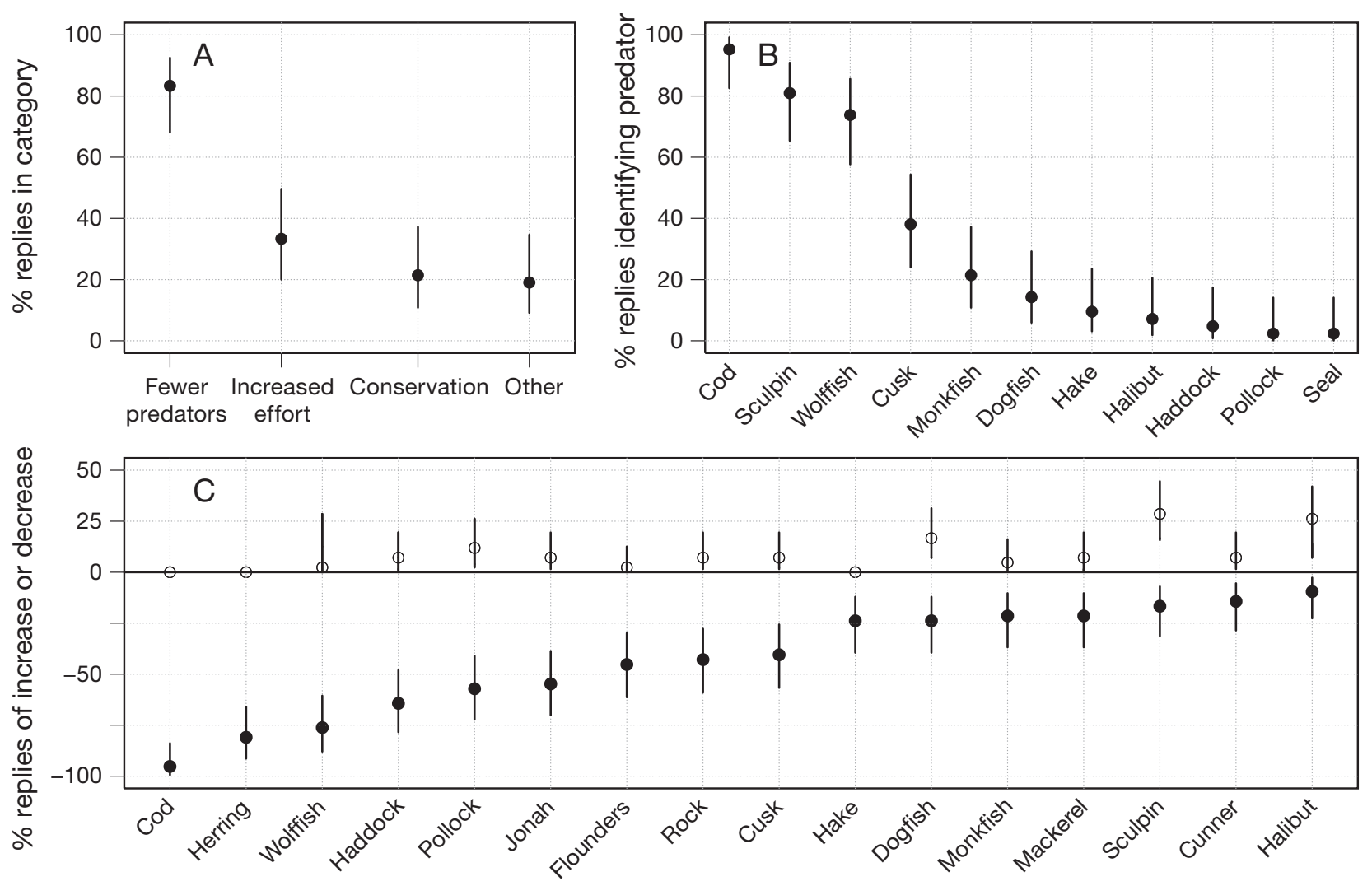

Fig. 2. Average responses, with $95 \% \mathrm{CI}$, to the 3 main survey questions (see 'Materials and methods'): (A) reasons given by the fishermen for the increase in lobster landings since 1980, (B) the percentage of fishermen who identified particular predators of lobsters based on their own sampling of stomach contents: Atlantic cod Gadus morhua, sculpin (Cottoidea), wolffish Anarhichas lupus, cusk Brosme brosme, monkfish Lophius americanus, spiny dogfish Squalus acanthias, hake Urophysis spp. and Merluccius bilinearis, Atlantic halibut Hippoglossus hippoglossus, haddock Melanogrammus aeglefinus, pollock Pollachius virens and grey seal Halichoerus grypus and (C) the percentage of fishermen who reported that a species has decreased (solid circles) or increased (open circles) in the inshore ecosystem throughout their careers; species not mentioned above: Atlantic herring Clupea harengus, Jonah crab Cancer borealis, flounders (Pleuronectidae), rock crab Cancer irroratus, Atlantic mackerel Scomber scombrus and cunner Tautogolabrus adspersus 
men's observations of lobster predators, 2 stomach content databases derived from trawl surveys were examined. The NEFSC stomach contents database (North Carolina to Nova Scotia, from 1973 to 2005, Table 1) revealed that smooth dogfish Mustelus canis, which is rarely observed in the GOM (Branstetter 2002), and cod had the highest proportions of lobster found in their stomachs. Longhorn sculpin, haddock and various hakes (e.g. Urophycis spp., Merluccius bilinearis) also preyed upon lobster. A much smaller inshore research trawl survey, conducted by the Maine DMR (2005 to 2007, not shown), found 1 lobster in a $\operatorname{cod}(\mathrm{N}=668$ stomachs examined) and another in a monkfish $(\mathrm{N}=289)$.

\section{Predator abundance}

The fishermen were asked to reflect on any population, besides lobster, that had undergone an increase or decrease in the inshore fishing grounds during their careers. Consistently, large-bodied fish, such as cod $(95 \%)$, wolffish $(76 \%)$ and haddock (64\%) were reported to have declined (Fig. 2C). There was no consensus, however, as to when precisely the cod populations had started to decline in nearshore areas: $2 \%$ thought that the decline began in the 1970s or before, $19 \%$ found this had happened in the early 1980s and $29 \%$ answered in the late 1980s. Similarly, in the 1990s, $19 \%$ observed cod abundance declining in nearshore waters early in the decade, and $17 \%$, late in the decade. Only sculpins and Atlantic halibut were identified more commonly as increasing, rather than as decreasing (Fig. 2C).

\section{Trawl survey estimates}

Regression analyses between the NMFS trawl surveys for combined groundfish predators $\left(R^{2}=0.3615\right.$, $\mathrm{p}<0.0001$; Fig. 3A), $\operatorname{cod}\left(\mathrm{R}^{2}=0.3616, \mathrm{p}<0.0001\right.$; Fig. 3C) and groundfish without $\operatorname{cod}\left(\mathrm{R}^{2}=0.1996, \mathrm{p}=\right.$ 0.0026; Fig. 3E) with lobster abundance indices all revealed negative and significant correlations. These negative correlations were largely driven by cod, with lobster increasing as cod abundance indices decreased in the trawl surveys. This negative correlation is also evident at time lags of 6 to $10 \mathrm{yr}$ and is usually strongest at around 0 to 4 yr (Fig. 3). When predators other than cod were examined individually with lobster, longhorn sculpin correlated positively $\left(\mathrm{R}^{2}=\right.$ 0.4742, $\mathrm{p}<0.0001)$, monkfish $\left(\mathrm{R}^{2}=0.1929, \mathrm{p}=0.0030\right)$ and cusk $\left(\mathrm{R}^{2}=0.2731, \mathrm{p}=0.0004\right)$ negatively, and wolffish trended negatively, but without statistical significance $\left(\mathrm{R}^{2}=0.0251, \mathrm{p}=0.1708\right)$.

\section{Changes in fishing effort}

The increase in landings in LFA 34 could in part be due to changes in fishing effort, such as expansion into deeper waters (FRCC 1995, Pezzack et al. 2001, DFO 2006a). The region referred to as the 'inshore' is composed of the nearshore and midshore areas. The traditional 'nearshore' grounds are $<55 \mathrm{~m}$ deep, with the expansion in fishing effort, documented since the 1980s, taking place in the deeper waters of the 'midshore'. The midshore ends at the boundary with LFA 41, which is considered the 'offshore' (DFO 2006a). Accordingly, $79 \%$ of interviewed fishermen have recently been fishing in deeper waters, with $60 \%$ of them starting to fish in these areas between the early 1980s and the early 2000s. However, $60 \%$ still spend some time fishing nearshore, and $19 \%$ spend their entire season there. There have been several reasons for this redistribution in fishing effort: $43 \%$ report more lobsters in deeper water, $29 \%$ prefer to avoid competition in nearshore waters and $24 \%$ follow the lobsters as they migrate seasonally from shallow to deeper water. Seventy-six percent were concerned that the increase in effective fishing effort would eventually cause the lobster population to decline, and $33 \%$ mentioned illegal fishing practices. The fishermen identified several ways to reduce fishing effort, such as lower trap limits, restricting fishing to daylight hours, closing the fishery for part of the season or $1 \mathrm{~d}$ each week. Traditionally lobster were found mostly on highly structured hard substrates, such as boulder fields, but over the past $10 \mathrm{yr}, 71 \%$ of the interviewed fishermen recorded that lobsters are now being found on other bottom types, such as soft sediments or mud (60\%).

There was no evidence for respondents' answers being biased in any way by their age or experience. The only exception was that their years of fishing experience correlated with when they started fishing in midshore waters $(p=0.0194)$. This result is intuitive, as the more years of experience a fisherman had at the time of the interview, the earlier they could have started fishing midshore.

\section{Other factors}

Temperature plays a major role throughout the lobster's life cycle (Aiken \& Waddy 1986). Fifty-five percent of the fishermen surveyed replied that the water temperature stays colder for longer into the spring, and $76 \%$ said that it is warmer into the fall. Nineteen percent felt that wind direction and strength had no effect on lobster landings, while $79 \%$ said that catch decreases with high winds.

In 1999, a parasitic paramoeba caused a massive lobster mortality event in Long Island Sound, USA 

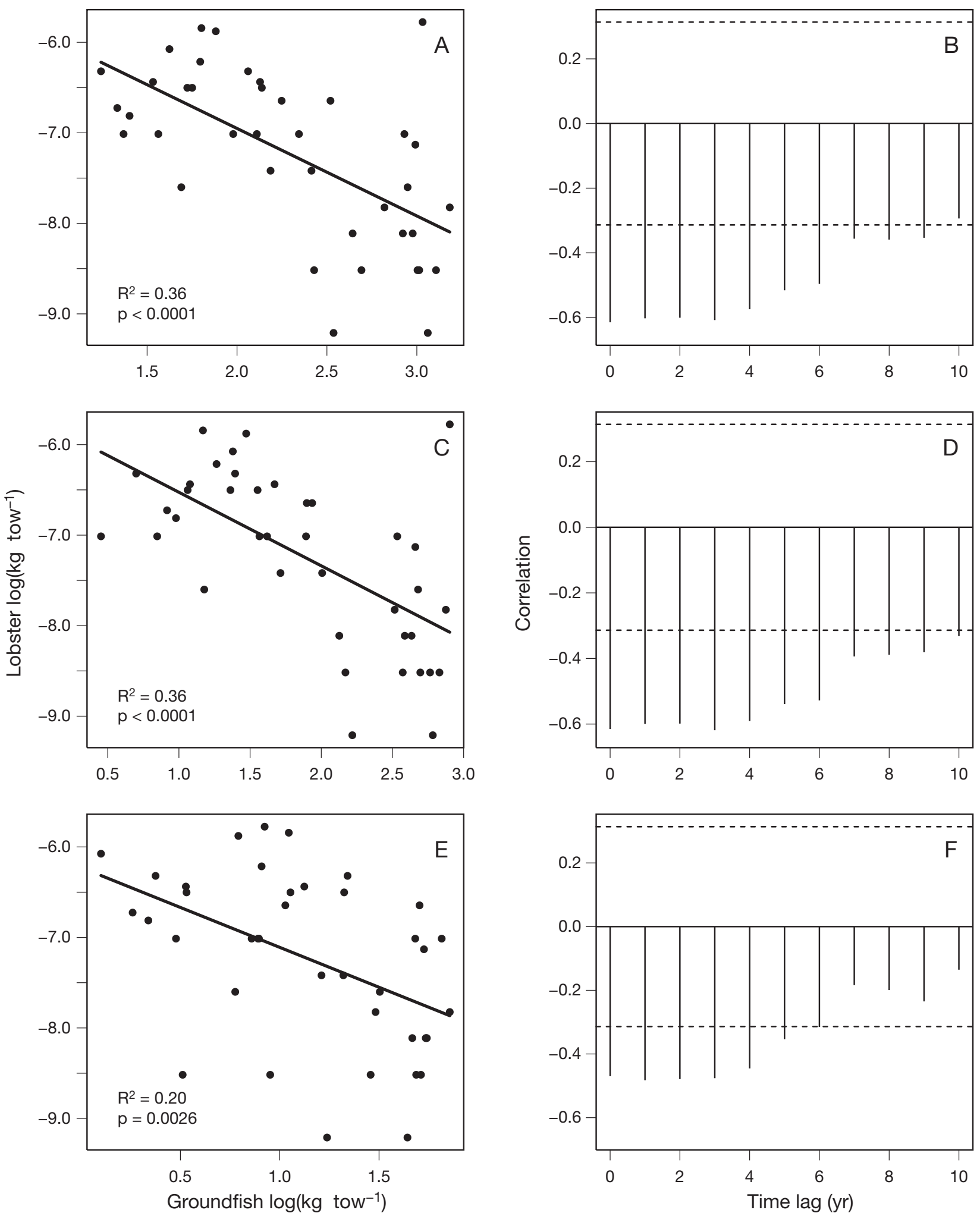

Fig. 3. Negative correlations between research trawl survey estimates of Gulf of Maine groundfish and lobster. National Marine Fisheries Service abundance indices $\left(\mathrm{kg} \mathrm{tow}^{-1}\right)$ were log-transformed, and correlations were tested at time lags from 0 to 10 yr. $(\mathrm{A}, \mathrm{B})$ Lobster abundance versus combined survey estimates of Atlantic cod, cusk, longhorn sculpin, monkfish and wolffish, $(\mathrm{C}, \mathrm{D})$ Atlantic cod and lobster, and $(\mathrm{E}, \mathrm{F}) 4$ groundfish predators of lobster, as above, but without cod. Dashed lines indicate $95 \%$ confidence intervals. Trendline and test statistics are from a linear regression on log-transformed data 
(Mullen et al. 2004). The effects of this disease were likely exacerbated by hypoxia and higher water temperatures (ASMFC 2006). Lobsters in the northeastern USA have also shown an increase in the incidence of shell disease in recent years, which largely causes deformations in lobsters being held for market, but is occasionally fatal (ASMFC 2006). Forty percent of the interviewed fishermen voiced a general concern about disease affecting the lobster population; however, 95\% had never or very rarely seen evidence of a diseased animal in their catch.

As for changes in prey abundance, 2 species of Cancer crab are known prey of juvenile and adult lobsters (Elner \& Campbell 1987, Lawton \& Lavalli 1995). Fifty percent of the fishermen surveyed were concerned that lobsters in LFA 34 were becoming food limited due to their high population density and to commercial catches of Jonah crab Cancer borealis by those with permits and for use as bait (DFO 2000). Cancer spp. were 2 of the top 5 species mentioned as being captured most commonly with lobster: cod (98\%), sculpin $(88 \%)$, Jonah crab $(86 \%)$, rock crab Cancer irroratus $(83 \%)$ and cusk $(64 \%)$.

It has been suggested that the large input of lobster bait (mostly the herring Clupea harengus) into the GOM has been subsidizing high lobster abundances (Saila et al. 2002). This argument is based on the fact that many lobsters exit the trap after feeding on bait (Karnofsky \& Price 1989, Jury et al. 2001). The average herring bait to lobster ratio in adjacent LFA 33 has been estimated to be as high as 1:1.9 (Harnish \& Willison 2009). While $40 \%$ of the fishermen in the present study felt that they were to some extent feeding lobsters with bait during the fishing season, for the majority of those interviewed it was not considered as a principal reason for the increase of lobsters in LFA 34.

\section{DISCUSSION}

This LEK survey provided evidence in support of the hypothesis that inshore lobster populations in the GOM have been released from predation, which may in part explain their high recruitment, abundance and landings. Despite high exploitation rates, whereby most of the new recruits are being caught every year, landings continue to be high. According to the fishermen interviewed, this may be explained partially by the extraordinary peak in lobster abundance and recruitment (Fig. 1) and partially by increased effort, conservation measures and possibly other factors (Fig. 2A). Fishermen's observations of predator diet and changes in abundance (Fig. 2B,C), as well as the observed decline in cod abundance and increase in lobster abundance, are all consistent with the hypothesized top-down mechanism (Fig. 3, Table 1).

These results add further support to the notion that the collapse of demersal predator populations, such as NW Atlantic cod, has released a suite of species from predation and contributed to a reorganization of the NW Atlantic inshore and shelf ecosystems (Worm \& Myers 2003, Steneck et al. 2004, Frank et al. 2005). More broadly, there is increasing evidence that topdown interactions and cascading ecosystem effects of fishing may be quite important both in nearshore and oceanic food webs (Heithaus et al. 2008, Baum \& Worm 2009). These interactions are typically mediated both by changes in prey density and behaviour (Heithaus et al. 2008). In this case, there is some evidence for both mechanisms leading to increased abundance of lobster and the reported expansion towards previously riskprone habitats. The observation that lobsters are venturing from structured hard substrates onto soft sediments has been independently confirmed by scientific studies which report that catch rates of lobster in trap surveys were higher on soft sediments than on hard substrates; however, lobster densities from diver surveys were higher on hard- than on soft-bottom types (Tremblay \& Smith 2001, Geraldi et al. 2009). Lobsters originally caught and released on soft substrates travelled significantly farther than those caught on hard substrates, indicating that the animals move faster over sediment in order to find more suitable habitat (Geraldi et al. 2009).

According to this survey, factors other than predation and fishing may play a limited role in regulating lobster populations in the GOM. Only $19 \%$ of fishermen observed that climate, disease, or changes in prey abundance were influential. Water temperature is often hypothesized to play a major role in the increased lobster landings in Maine and Nova Scotia. In Maine (1946 to 1986), $54 \%$ of the variance in lobster landings could be explained by the sea-surface temperature (SST) at the time of larval settlement (Steneck \& Wilson 2001). In Nova Scotia (1929 to 1970), $68 \%$ of the variance in landings was explained by the SST in St. Andrews, New Brunswick, in addition to the previous year's catch (Flowers \& Saila 1972). Drinkwater et al. (1996), on the other hand, were not able to link SST with the increase in lobster landings throughout the American lobster's range in the 1980s and early 1990s, although they acknowledged a potential role of SST in the past. From the present LEK survey, it is evident that the fishermen pay close attention to changes in water temperature, which affects lobster movement, moulting and spawning, and they are keenly aware of environmental cycles. However, water temperature did not emerge in the replies as a main driver of the increase in lobster. 
Likewise, bait inputs were not considered as a major mechanism to boost lobster populations in LFA 34, though $40 \%$ agreed that lobsters were likely eating bait during the fishing season from late November to the end of May. Bait inputs may be more substantial on the United States' side of the GOM, where trap density is higher and the fishery operates year-round (Myers et al. 2007, Grabowski et al. 2009). Despite the higher bait input, however, the relative increase in lobster landings has been less pronounced in the United States compared with Canadian waters (Myers et al. 2007), and, in the eastern portions of the GOM, bait is not believed to subsidize lobster populations (Grabowski et al. 2009).

Ecological knowledge surveys may best be used in combination with other data sources, so that fishermen's observations can be verified independently. One contrasting example comes from the southern Gulf of Saint Lawrence (sGSL; Davis et al. 2004), where fishermen were concerned that research survey protocols were insufficient to document the predation of white hake Urophycis tenuis on juvenile lobster. Fishermen did provide accurate details of hake distribution, yet stomach sampling revealed that, contrary to the belief of fishermen, white hake did not ingest lobster $(\mathrm{N}=$ 3080). In our study, the fishermen revealed detailed insights into potential predators of lobsters and other aspects of the coastal ecosystem, such as shifts in species composition, water temperatures, habitat expansion and the incidence of disease. By comparing their replies with the trawl survey-derived stomach content and abundance data, it seems evident that the LEK for LFA 34 reflects some of the ecosystem changes in the GOM. Interviewees consistently reported that large fish had declined in abundance and that those same large fish were predators of lobster. Atlantic cod stood out as the species that was most consistently reported as having declined and as being a predator of lobster. While the proportion of lobsters found in fish stomachs is small overall (Table 1), the predation of a large cod stock upon lobsters could still have had a significant effect, particularly when considering the historical biomass of cod in the GOM and Scotian Shelf area (Steneck 1997, Rosenberg et al. 2005).

In a study of the sGSL, Atlantic cod reportedly ingested lobster at a much lower rate than those in the present study, with lobster being found in $0.05 \%$ of cod stomachs between 1990 and 1996. Most size classes of cod, however, overlapped spatially with lobsters in the sGSL only during June and October. There were no significant relationships between cod and lobster abundance indices (1950 to 1996) for time lags of 0 to $7 \mathrm{yr}$, indicating that cod did not control lobster abundance in the sGSL. However, the study identified shorthorn sculpin Myoxocephalus scorpius, cunner
Tautogolabrus adspersus and white hake as potential predators of lobster (Hanson \& Lanteigne 2000). A second study in the northeastern USA collected $>15000$ cod stomachs from the NEFSC seasonal bottom trawl survey between Cape Hatteras, North Carolina, and SW Nova Scotia from 1973 to 1998. Commercially valuable decapods were determined to be an important component of the diet of Atlantic cod; however, American lobster was not identified as a major prey item. The study concluded that cod were opportunistic generalists and that it was not likely that cod exerted predatory control on all of its prey populations in the United States' northwestern Atlantic (Link \& Garrison 2002).

One of the key challenges of LEK surveys is determining whether or not the respondent is giving a reply that they think the interviewer wants to hear, potentially by being led by the interviewer. To address this, there were 2 versions of the respondent's consent form, the first mentioned the loss of groundfish as a potential mechanism for the increased lobster landings and the second did not. No differences were found between responses to the 2 versions, indicating respondents were not led by the consent form. Another potential challenge in the present study was our relatively small sample size; roughly $4.5 \%$ of the license owners were interviewed, coming close to our goal of $5 \%$. As a comparison, Hutchings \& Ferguson (2000) interviewed 47 fishermen of a similar demographic in 2 sectors of Newfoundland's fixed-gear cod fishery. Their sample represented $1 \%$ of 4677 fishermen, yet they were able to establish patterns in the harvesting of cod from 1980 to 1991 that were consistent with the hypothesis that the decline in Newfoundland's inshore cod stock was gradual. We targeted fishermen with decades of experience who were viewed as local experts by their peers. The considerable agreement between respondents for most answers indicated that a higher sample size would not likely have changed the results.

It is possible for a respondent to reply in such a way that serves personal motives, particularly if the interviewee has a high stake in the outcome (Gendron et al. 2000). We note, however, that this survey did not question fishermen about the abundance of lobsters (which was assumed to be high) or their personal catches and that the ecological hypotheses we explored would not necessarily influence lobster management. In an effort to minimize any further potential for personal biases we targeted experienced fishermen, some of whom would be near retirement. These fishermen were often very candid and forthcoming, and there was little sense of hesitation, bias, or staged answers.

In conclusion, we suggest that LEK surveys are a useful method to learn more about how fisheries may affect ecosystems, especially when they can comple- 
ment independently collected scientific data. Canadian fisheries are now largely dependent on lower trophic levels (Pauly et al. 2001), with a heavy emphasis on benthic invertebrates. Unfortunately, the knowledge base for many of these fisheries is slim, and fisheries-independent data or proper assessments are often not available (Anderson et al. 2008). It seems prudent in this case to use all of the available information, including fishermen's expert knowledge as one possible line of evidence, to evaluate ecological interactions and to inform the management process.

Acknowledgements. The authors extend their thanks to the LFA 34 fishermen for sharing their knowledge and making this work possible, to C. E. den Heyer, D. J. Fraser \& S. D. Fuller for their expertise and experience in ecological knowledge, to C. M. Denton \& V. A. Deviller for support and contacts in the LFA, to M. J. Fogarty \& S. Sherman for providing datasets, to M. J. Tremblay \& D. S. Pezzack, for helpful discussions and guidance, to S. C. Anderson, W. Blanchard \& C. Minto for statistical support, to NSERC for funding the present study and to the late R. A. Myers for his inspiration.

\section{LITERATURE CITED}

Aiken DE, Waddy SL (1986) Environmental influence on recruitment of the American lobster, Homarus americanus: a perspective. Can J Fish Aquat Sci 43:2258-2270

Anderson SC, Lotze HK, Shackell NL (2008) Evaluating the knowledge base for expanding low-trophic-level fisheries in Atlantic Canada. Can J Fish Aquat Sci 65:2553-2571

ASMFC (Atlantic States Marine Fisheries Commission) (2006) American lobster assessment for peer review. Stock assessment report No. 06-03 (suppl), ASMFC, Washington, DC

Baum JK, Worm B (2009) Cascading top-down effects of changing oceanic predator abundances. J Anim Ecol 78: 699-714

Berkes F, Hughes TP, Steneck RS, Wilson JA and others (2006) Globalization, roving bandits, and marine resources. Science 311:1557-1558

Branstetter S (2002) Smooth dogfishes, family Triakidae. In: Collette BB, Klein-MacPhee G (eds) Bigelow and Schroeder's fishes of the Gulf of Maine, 3rd edn. Smithsonian Institution Press, Washington, DC, p 37-38

Clark DS, Emberley J (2009) Assessment of cod in division 4X in 2008. DFO Can Sci Advis Sec Res Doc 2009/18, Canadian Department of Fisheries and Oceans, Ottawa, Ontario

Collie JS, Wood AD, Jeffries HP (2008) Long-term shifts in the species composition of a coastal fish community. Can J Fish Aquat Sci 65:1352-1365

Davis A, Wagner JR (2003) Who knows? On the importance of identifying 'experts' when researching local ecological knowledge. Hum Ecol 31:463-489

Davis A, Hanson JM, Watts H, MacPherson H (2004) Local ecological knowledge and marine fisheries research: the case of white hake (Urophycis tenuis) predation on juvenile American lobster (Homarus americanus). Can J Fish Aquat Sci 61:1191-1201

DFO (Canadian Department of Fisheries and Oceans) (1997) Lobster LFA 34 SW Nova Scotia. DFO Atlantic Fisheries Stock Status Rep 96/118E, DFO, Ottawa, ON

DFO (2000) Inshore Gulf of Maine Jonah crab. DFO Sci Stock Status Rep C3-66, DFO, Ottawa, ON
DFO (2006a) Framework assessment for lobster (Homarus americanus) in lobster fishing area (LFA) 34. DFO Can Sci Advis Sec Sci Advis Rep 2006/024, DFO, Ottawa, Ontario

DFO (2006b) An assessment of American lobster in Newfoundland. DFO Can Sci Advis Sec Sci Advis Rep 2006/ 009, DFO, Ottawa, ON

DFO (2007) Framework and assessment for lobster (Homarus americanus) in the southern Gulf of St. Lawrence lobster fishing areas 23, 24, 25, 26A, and 26B. DFO Can Sci Advis Sec Sci Advis Rep 2007/035, DFO, Ottawa, ON

> Drinkwater KF, Harding GC, Mann KH, Tanner N (1996) Temperature as a possible factor in the increased abundance of American lobster, Homarus americanus, during the 1980s and early 1990s. Fish Oceanogr 5:176-193

Elner RW, Campbell A (1987) Natural diets of lobster Homarus americanus from barren ground and macroalgal habitats off southwestern Nova Scotia, Canada. Mar Ecol Prog Ser 37:131-140

Flowers JM, Saila SB (1972) An analysis of temperature effects on the inshore lobster fishery. J Fish Res Board Can 29:1121-1125

> Frank KT, Petrie B, Choi JS, Leggett WC (2005) Trophic cascades in a formerly cod-dominated ecosystem. Science 308:1621-1623

> Frank KT, Petrie B, Shackell NL (2007) The ups and downs of trophic control in continental shelf ecosystems. Trends Ecol Evol 22:236-242

FRCC (Fisheries Resource Conservation Council) (1995) A conservation framework for Atlantic lobster: report to the Minister of Fisheries and Oceans. FRCC 95.R.1. FRCC, Ottawa, ON

FRCC (Fisheries Resource Conservation Council) (2007) Sustainability framework for Atlantic lobster 2007: report to the Minister of Fisheries and Oceans. FRCC 07.R1. FRCC, Ottawa, ON

Gendron L, Archambault J (1997) Change in fishing capacity in the American lobster (Homarus americanus) fishery of the Magdalen Islands (Québec) from 1975 to 1995. Can Tech Rep Fish Aquat Sci 2189

Gendron L, Camirand R, Archambault J (2000) Knowledgesharing between fishers and scientists: towards a better understanding of the status of lobster stocks in the Magdalen Islands. In: Neis B, Felt L (eds) Finding our sea legs. ISER Books - Faculty of Arts Publications, St. John's, NL, p 6-71

Geraldi NR, Wahle RA, Dunnington M (2009) Habitat effects on American lobster (Homarus americanus) movement and density: insights from georeferenced trap arrays, seabed mapping, and tagging. Can J Fish Aquat Sci 66:460-470

Grabowski JH, Gaudette J, Clesceri EJ, Yund PO (2009) The role of food limitation in lobster population dynamics in coastal Maine, United States, and New Brunswick, Canada. N Z J Mar Freshw Res 43:185-193

> Hanson JM, Lanteigne M (2000) Evaluation of Atlantic cod predation on American lobster in the southern Gulf of St. Lawrence, with comments on other potential fish predators. Trans Am Fish Soc 129:13-29

Harnish L, Willison JHM (2009) Efficiency of bait usage in the Nova Scotia lobster fishery: a first look. J Clean Prod 17: 345-347

> Heithaus MR, Frid A, Wirsing AJ, Worm B (2008) Predicting ecological consequences of marine top predator declines. Trends Ecol Evol 23:202-210

> Hutchings JA, Ferguson M (2000) Temporal changes in harvesting dynamics of Canadian inshore fisheries for northern Atlantic cod, Gadus morhua. Can J Fish Aquat Sci 57: 805-814 
Jury SH, Howell H, O'Grady DF, Watson WH III (2001) Lobster trap video: in situ surveillance of the behaviour of Homarus americanus in and around traps. Mar Freshw Res 52:1125-1132

Karnofsky EB, Price HJ (1989) Behavioural response of the lobster Homarus americanus to traps. Can J Fish Aquat Sci 46:1625-1632

Kirby MX (2004) Fishing down the coast: historical expansion and collapse of oyster fisheries along continental margins. Proc Natl Acad Sci USA 101:13096-13099

Lawton P, Lavalli KL (1995) Postlarval, juvenile, adolescent, and adult ecology. In: Factor JR (ed) Biology of the lobster Homarus americanus. Academic Press, San Diego, CA, p 47-88

Link JS, Garrison LP (2002) Trophic ecology of Atlantic cod Gadus morhua on the northeast US continental shelf. Mar Ecol Prog Ser 227:109-123

Lopes CS, Rodrigues LC, Sichieri R (1996) The lack of selection bias in a snowball sampled case-control study on drug abuse. Int J Epidemiol 25:1267-1270

Lotze HK, Milewski I (2004) Two centuries of multiple human impacts and successive changes in a North Atlantic food web. Ecol Appl 14:1428-1447

Mullen TE, Russell S, Tucker MT, Maratea JL and others (2004) Paramoebiasis associated with mass mortality of American lobster Homarus americanus in Long Island Sound, USA. J Aquat Anim Health 16:29-38

Murray G, Neis B, Johnsen JP (2006) Lessons learned from reconstructing interactions between local ecological knowledge, fisheries science, and fisheries management in the commercial fisheries of Newfoundland and Labrador, Canada. Hum Ecol 34:549-571

Myers RA, Boudreau SA, Kenney RD, Moore MJ, Rosenberg AA, Sherrill-Mix SA, Worm B (2007) Saving endangered whales at no cost. Curr Biol 17:R10-11

Neis B, Felt LF, Haedrich RL, Schneider DC (1999a) An interdisciplinary method for collecting and integrating fishers' ecological knowledge into resource management. In: Newell D, Ommer RE (eds) Fishing places, fishing people: traditions and issues in Canadian small-scale fisheries. University of Toronto Press, Toronto, ON, p 217-238

Neis B, Schneider DC, Felt L, Haedrich RL, Fischer J, Hutchings JA (1999b) Fisheries assessment: What can be learned from interviewing resource users? Can J Fish Aquat Sci 56:1949-1963

Neuman WL (2000) Social research method: qualitative and quantitative approaches, 4th edn. Allyn and Bacon, Needham Heights, MA

Newcombe RG (1998) Two-sided confidence intervals for the single proportion: comparison of seven methods. Stat Med 17:857-872

Olsson P, Folke C (2001) Local ecological knowledge and institutional dynamics for ecosystem management: a study of Lake Racken Watershed, Sweden. Ecosystems 4: 85-104

Orensanz JM, Armstrong J, Armstrong D, Hilborn R (1998)

Editorial responsibility: Otto Kinne,

Oldendorf/Luhe, Germany
Crustacean resources are vulnerable to serial depletionthe multifaceted decline of crab and shrimp fisheries in the greater Gulf of Alaska. Rev Fish Biol Fish 8:117-176

> Pauly D, Palomares ML, Froese R, Sa-a P, Vakily M, Preikshot D, Wallace S (2001) Fishing down Canadian aquatic food webs. Can J Fish Aquat Sci 58:51-62

Pezzack DS, Frail CF, Lawton P, Robichaud DA, Strong MB (2001) Update on stock status of American lobster, Homarus americanus, lobster fishing area 34. DFO Can Sci Advis Sec Res Doc 2001/156, , DFO, Ottawa, ON

R Development Core Team (2008) R: a language and environment for statistical computing. R Foundation for Statistical Computing, Vienna. Available at: www.R-project.org

> Rosenberg AA, Bolster WJ, Alexander KE, Leavenworth WB, Cooper AB, McKenzie MG (2005) The history of ocean resources: modeling cod biomass using historical records. Front Ecol Environ 3:78-90

Sáenz-Arroyo A, Callum MR, Torre J, Carino-Olvera M, Enriquez-Andrade RR (2005a) Rapidly shifting environmental baselines among fishers of the Gulf of California. Proc Biol Sci 272:1957-1962

Sáenz-Arroyo A, Callum MR, Torre J, Carino-Olvera M (2005b) Using fishers' anecdotes, naturalists' observations and grey literature to reassess marine species at risk: the case of the Gulf Grouper in the Gulf of California, Mexico. Fish Fish 6:121-133

> Saila SB, Nixon SW, Oviatt CA (2002) Does lobster trap bait influence the Maine inshore trap fishery? N Am J Fish Manage 22:602-605

Steneck RS (1997) Fisheries-induced biological changes to the structure and function of the Gulf of Maine ecosystem. In: Wallace GT, Braasch EF (eds) Proceedings of the Gulf of Maine Ecosystem Dynamics Scientific Symposium and Workshop. Regional Association for the Research on the Gulf of Maine (RARGOM Report 91-1), Hanover, NH

Steneck RS (2006) Is the American lobster, Homarus americanus, overfished? A review of overfishing with an ecologically based perspective. Bull Mar Sci 78:607-632

> Steneck RS, Wilson CJ (2001) Large-scale and long-term, spatial and temporal patterns in demography and landings of the American lobster, Homarus americanus, in Maine. Mar Freshw Res 52:1303-1319

Steneck RS, Vavrinec J, Leland AV (2004) Accelerating trophic-level dysfunction in kelp forest ecosystems of the western North Atlantic. Ecosystems 7:323-332

Tegner MJ, Dayton PK (2000) Ecosystem effects of fishing in kelp forest communities. ICES J Mar Sci 57:579-589

> Tremblay MJ, Smith SJ (2001) Lobster (Homarus americanus) catchability in different habitats in late spring and early fall. Mar Freshw Res 52:1321-1331

Worm B, Myers RA (2003) Meta-analysis of cod-shrimp interactions reveals top-down control in oceanic food webs. Ecology 84:162-173

Zhang Y, Chen Y (2007) Modeling and evaluating ecosystem in 1980s and 1990s for American lobster (Homarus americanus) in the Gulf of Maine. Ecol Model 203:475-489

Submitted: July 23, 2009; Accepted: December 23, 2009

Proofs received from author(s): March 7, 2010 